\title{
Tasers in medicine: an irreverent call for proposals
}

\author{
Published at www.cmaj.ca on May I, 2008.
}

I $\mathrm{n}$ this issue, we call your attention to an emerging and increasingly popular medical device: the taser. It may strike you as odd to hear tasers described as medical devices. Tasers are probably more familiar to you, depending on your point of view, as a valuable tool for subduing criminals and safeguarding the lives of law enforcement personnel ${ }^{1}$ or, alternatively, as a potentially lethal weapon being deployed with wanton disregard for public safety. ${ }^{2}$ The latter perspective has possibly been inflicted on society by the media, which has an annoying habit of publicizing when someone dies after being exposed to a taser discharge. In fact, media reports to date have documented over 300 such deaths, 20 in Canada. ${ }^{3,4}$ Critics charge that tasers are too dangerous, that independent studies evaluating their safety are urgently needed and that a moratorium should be placed on their use. ${ }^{2-4}$

Fortunately, comforting words can be found if you're looking for reassurance that tasers really are the greatest invention since pepper spray - another weapon that medicine has appropriated, now that capsaicin cream is used as a topical analgesic. You see, despite what scientific demonstration of potentially lethal effects in animals and humans (as reviewed by Nanthakumar and colleagues in this issue $e^{5}$, overwhelming circumstantial evidence and a certain notorious airport video might lead you to believe, tasers are perfectly safe and have never, ever killed anyone. We know this because TASER International, manufacturer of the marketleading device, says so, claiming "the TASER ECD cannot stop the heart". ${ }^{6}$ And TASER International is an honourable, and for most of its existence very profitable, company.

So honourable, in fact, that they have sponsored research to prove the taser's safety. Just about all the research, as it turns out. ${ }^{7}$ Moreover, they pay for experts to travel across North America and spread the good news about how safe tasers are and correct any misconceptions that might arise from events like deaths of suspects in police custody or immigrants in Vancouver's airport. ${ }^{8}$ They even set up demonstration booths where, like some bizarre extreme sport, people line up voluntarily to experience a taser shock for themselves. ${ }^{9}$ Notably, volunteers are almost always shocked in the back and not in the chest, where the electrodes might cross the heart, nor do volunteers experience the repeated and sustained shocks that are often used in the field, a feature that has led the United Nations to classify the taser as a form of torture. ${ }^{10}$

TASER International appears to attract loyalty. The scientific literature bears witness to a small group of dedicated researchers who diligently write letters to journals pointing out flaws in studies reporting harm from tasers. Unfortunately, some of these researchers occasionally neglect to mention their participation on TASER International's medical advisory board or board of directors. ${ }^{11,12}$ TASER International itself sometimes goes further, to the extent of suing a researcher for publishing scientific results critical of tasers in a peer-reviewed journal and a medical examiner for the "error" of listing taser exposure on a death certificate as the cause of death. ${ }^{13}$ Obviously, no one is better suited to instruct a qualified physician, coroner or specialist in forensic pathology on how to determine the cause of death than advisors to a corporation with a vested interest in the device being critiqued. This bold step ushers in a new medico-legal era: physicians can now be sued not only for delivering bad care but also for holding bad opinions.

Owing to these diligent efforts, the taser's good reputation has been maintained. Law enforcement agencies worldwide are increasingly adopting its use. In the United States, the general public can also exercise their second-amendment right to bear tasers, with the latest consumer models sporting stylish leopard print or camouflage motifs.

And now, apparently, it is medicine's turn. You see, the company and its hired experts have managed to explain why so many people seem to die after being zapped by a taser without this being in any way the fault of the device. They have taught us about an emerging disorder called "excited delirium." As reported recently in $C M A J{ }^{14}$ this disorder, which does not officially exist as a recognized clinical condition in the DSM-IV classification, enjoys lively discussion whenever tasers are involved. The message to remember is that tasers do not kill people: excited delirium does. Only cynics would observe that tasers nevertheless appear to be the leading risk factor associated with sudden death due to excited delirium, suggesting a potential cure for this increasingly prevalent and fatal condition if society could accept the drastic measure of withdrawing tasers from use.

Despite this, some law enforcement training materials actually discuss excited delirium as an indication for taser use,${ }^{15}$ which is a position endorsed by the manufacturer. As it seems from this that tasers are being recommended as a treatment for a medical condition, we infer that they are in effect being construed as a medical device. Now, we have some bad news for the manufacturer. To be approved for use, medical devices must satisfy rigourous scientific standards and be subjected to clinical trials. This is to protect the public from unsafe medical devices. Fortunately for TASER International, there are no similarly rigourous scientific standards mandated to protect the public from potentially unsafe law enforcement devices. Tasers can thus be used freely on any member of the population, albeit safeguarded by the sound judgment of law enforcement personnel and, in the United States, by the sound judgment of most any adult who has money to purchase one.

To keep health care professionals from being excluded from this exciting treatment option, perhaps the Canadian Institutes of Health Research should issue a call for proposals for taser research. A randomized trial of tasers for excited 
delirium would seem a logical place to start, but given the lack of an accepted case definition for this condition, a study in ordinary delirium might have to do. For those who might have ethical concerns with such a trial, we point out that a management strategy currently popular in this context, the off-label use of antipsychotics, is already known to increase the risk of death, ${ }^{16}$ thus one could argue that clinical equipoise exists as to whether tasers would be a safer and more effective intervention. The emergency department may be a safer environment to study taser use because, curiously, patients rarely seem to die of excited delirium in an emergency department and physicians' hearts are comforted by the presence of a defibrillator.

On the other hand, perhaps the CIHR should issue a different kind of call. The CIHR could start by recognizing that deaths occurring in association with taser use make the safety of these devices a public health issue. New and independent research, both epidemiologic and biological, into whether tasers can kill is essential to settle this issue. Also, law enforcement agencies could be made to open up their databases on taser use for independent analysis, on the principle that the assertion that tasers have saved lives of police and suspects alike, while plausible, should be proven, not merely asserted as fact. We imagine that, to TASER International, this type of research may seem unnecessary and pedantic. We're sorry, but in the end, we are used to thinking like physicians and scientists concerned about health, preferring to gather and analyze the facts rather than succumbing to the bald assertions of a large corporate entity that has demonstrated a willingness to squelch any messages that could hurt its bottom line.

\author{
Matthew B. Stanbrook MD PhD \\ Deputy Editor, Scientific, CMAJ \\ With the Editorial-Writing Team (Paul C. Hébert MD MHSc, \\ Rajendra Kale MD, Barbara Sibbald BJ, Ken Flegel MDCM MSc \\ and Noni MacDonald MD MSc)
}

Competing interests: See www.cmaj.ca/misc/edboard.shtml

\section{REFERENCES}

I. Klint DE. TASER device liability and litigation risk. Scottsdale (AZ): TASER International; 2007. Available: www.Taser.com/research/Legal/Pages/TASERDeviceLiabilityandRisk.aspx (accessed 2008 Apr I5).

2. Amnesty International's concerns about Tasers. Ottawa: Amnesty International Canada; 2007. Available: www.amnesty.ca/themes/tasers_backgrounder.php (accessed 2008 Apr I5)

3. Amnesty International reiterates call to suspend police use of tasers following airport death [news release]. Ottawa $(\mathrm{ON})$ : Amnesty International Canada; 2007. Available: www.amnesty.ca/resource_centre/news/view.php?load=arcview\&article $=4117 \& \mathrm{c}=$ Resource+Centre+News (accessed 2008 Apr I5).

4. TNT - TRUTH...not TASERS [blog]. Available: http://truthnottasers.blogspot .com/ (accessed 2008 Apr I5).

5. Nanthakumar K, Massé S, Umapathy K, et al. Cardiac stimulation with high voltage discharge from stun guns CMAJ 2008; I78:I45I-7.

6. Kroll MW. Cardiac safety. Scottsdale (AZ): TASER International; 2007 Mar 25 Available: www.taser.com/research/Science/Pages/CardiacSafety.aspx (accessed 2008 Apr I5).

7. Anglen R. Taser tied to "independent" study that backs stun gun. Arizona Republic 2005 May 2I. Available: www.azcentral.com/arizonarepublic/news/articles 1052ITaserDOD2I.html\# (accessed 2008 Apr I4).

8. Alphonso C, Leeder J, El Akkad O. Taser firms picked up coroner's tab to give lectures. The Globe and Mail 2007 Nov 30. Available: www.theglobeandmail.com/servlet /story/LAC.2007II30.TASER3o/TPStory/TPNational/Ontario/ (accessed 2008 Apr I5).

9. Basler R. Oh, we're playing LASER tag? Not TASER tag? My bad... London (UK): Reuters; 2007. Available: http://blogs.reuters.com/blog/2007/or/18/oh-were-playing -laser-tag-not-taser-tag-my-bad/ (accessed 2008 Apr I5).

Io. United Nations Office at Geneva. Committee against torture concludes thirty-ninth session. Geneva: United Nations; 2007. Available: www.unog.ch/80256EDD oo6B9C2E/(httpNewsByYear_en)/D3DD9DE87B278A87CI25739Coo54A8IC?Open Document (accessed 2008 Apr I5).

II. Kroll M, Luceri RM, Calkins H. A very interesting case study involving a TASER conducted electrical weapon (CEW) used on a patient with a pacemaker. J Cardiovasc Electrophysiol 2007;18:E29-30.

I2. Kroll MW, Calkins H, Luceri RM. Electronic control devices and the clinical milieu. J Am Coll Cardiol 2007;49:732-3.

13. Randerson J. Stun gun makers sue experts over safety criticisms. Guardian (UK) 2006 Mar 9. Available: www.guardian.co.uk/science/2006/mar/og/uknews (accessed 2008 Apr I5).

14. Truscott A. A knee in the neck of excited delirium. CMAJ 2008;178:669-70.

15. Royal Canadian Mounted Police. Operational manual. Chapter 17.7: Conducted energy weapon. Ottawa: the Police; 2007. Available: www.rcmp.ca/ccaps lops_17_7_e.htm (accessed 2008 Apr. 15).

I6. Singh S, Wooltorton E. Increased mortality among elderly patients with dementia using atypical antipsychotics. CMAJ 2005;173:252. 